Vol. 5, No. 1, 2018

UDC 334.758

\author{
V. Kozyk \\ $\mathrm{PhD}$ in Economics, Professor
}

Kh. Zalytska

$\mathrm{PhD}$ in Economics, Associate Professor

V. Zalutsky

$\mathrm{PhD}$ in Economics, Associate Professor

Lviv Polytechnic National University

\title{
HYBRID DEVELOPMENT OF MODERN ENTERPRISES
}

\begin{abstract}
Long-term effective development of enterprises in the modern dynamic conditions, as a rule, provides the use of certain variants of integration or diversification growth. However, as research shows, in many cases it is advisable to choose a hybrid variant of such growth due to the formation of business structures by combining concrete business units of several enterprises. At the same time, enterprises whose business units are involved in the formation of hybrid structures can continue their normal functioning with other own business units, using the residual capabilities of business units that are part of the hybrid structure. With the help of comparative analysis, generalization and system approach in the work, variants of hybrid growth are highlighted and one of them is described for the tourist industry. The efficiency of the ski resort with the use of concentric growth strategies, concentric and conglomerate diversification, and hybrid growth are calculated. The results confirmed the effectiveness of hybrid growth for enterprises with insufficient financial resources and strategic opportunities and successful enterprises by integrating certain business units of one enterprise with specialized business units of other enterprises. The difficulties of using hybrid growth variants for enterprises of other industries are determined and recommendations for their solution are given.
\end{abstract}

Key words: diversification; integration; hybrid growth; business unit; strategy.

\section{Formulation of the problem}

One of the most effective ways of modern enterprise activity is diversified or integration growth, which ultimately provides a successful long-term development of the enterprise. At the same time, diversified growth is ensured by the formation of effective measures of competition in a certain market through the release of a new nontraditional technology, marketing or consumer product position, and integration - by establishing the best options for cooperation with suppliers, consumers, intermediaries, competitors, other subjects of management.

However, one-way orientation of the enterprise into one of the above-mentioned directions can lead to its destruction in the long run due to:

- strict competition, which, in addition to significant costs, can help to unite competitors against the company in order to withdraw it from the market;

- orientation towards unification, which may lead to dependence and control from enterprises with which cooperation is established;

- the presence of enterprises at different stages of development with significantly different financial, marketing, innovation opportunities, etc.

In addition, not all enterprises can apply these development options. For example, an expedient development direction for a company with weak financial resources is the reduction of production, and for a company that is in a stage of decline in the life cycle - liquidation or restructuring.

Therefore, an important point is the need for a rational and timely solution to the question: when and where to compete, and when to cooperate, so that it would be beneficial to all interacting subentities of the economy irrespective of their financial status, developmental possibilities and life-cycle stage. There is a need to introduce a development option that would combine the 


\section{Kozyk, Kh. Zalytska, V. Zalutsky}

features of each of the above approaches. That is, the question is about the formation of hybrid variants of development, which would ensure the establishment of a rational balance between competition and cooperation.

\section{The recent investigations and publications}

The scientific literature describes widely the variants of diversification and forms of integration of enterprise activity [1-12]. Diversification is a common form of development of foreign and some domestic enterprises. Of particular relevance is the diversification of enterprises with the allocation of business units according to certain classification characteristics and their subsequent successful longterm functioning by finding opportunities for optimal and effective interaction between them. The results of research [13] confirm that the operation of business units in the form of business units brings far more effect than their individual management. In particular, the effectiveness of our proposed division of the Zakhar Berkoot Resort is not only on the business unit (BU), but also on the strategic business units (SBUs), helping (HBU) and providing (PBU) business units, is confirmed by positive results. Its functioning as an integral unit due to the formed synergy effect. However, diversification requires significant spending to form strategic development opportunities, which can be achieved with reduced costs by combining with other enterprises or their business units. Therefore, the question of finding ways to combine the possibilities of integration and diversification growth, to create possible effective hybrid directions for enterprise development, requires detailed research.

\section{Statement of purpose}

The goal of the rsearch is to create options for hybrid growth of enterprises based on the benefits of diversification and integration of their business units.

\section{Description of the main study material and the results}

Taking into account the peculiarities of the division of enterprises in the SBU, HBU and PBU $[14,15]$, as well as the conditions and forms of integrated growth, the proposed variants of hybrid growth are presented in Fig. 1.

According to the first variant of the hybrid growth of enterprises 1,2 and 3 are divided into SBU, HBU and PBU. For further operation, they can unite in one company, whose effective operation will be provided only by certain business units of all three enterprises. The presence of one integrated enterprise, the rest of the business units of units of all interacting enterprises, will incur unnecessary costs. That is, the performance of all three enterprises in the form of business units with the formation of a hybrid structure will be more productive, by combining the SBU of one enterprise with the HBU and the PBU of others. In this case, the PBU and HBU of the parent company may be stored, and the activities of some of them may be reduced.

Considered variants of hybrid growth (Fig. 1) can be used also in the formation of international clusters, when one of the enterprises 1,2 or 3 is located in another country.

Each of the variants of the hybrid growth of the company provides him with a certain synergistic effect, which manifests itself in the advantages:

- the general ones that are present for all structural elements of the created hybrid structure (SBU, HBU and PBU) and manifested in reducing or eliminating certain trade barriers, combining and wider use of resources and potentials of two or more enterprises, avoiding competition from partners, the best knowledge of the needs and preferences of local consumers and the requirements and conditions of the functioning of this market, the more effective application of special skills and knowledge, increased differentiation of goods / services, rapid entry into the market, increasing the potential for learning, decision of consumers as domestic producers need less investment;

- specific, namely, for:

- SBU is a low cost due to the use of cheap labor, raw materials, materials, etc.; better quality of products at the expense of manufacturer's specialization; close placement to the manufacturer of products;

-HBU is the emergence of a stable market share; no need to adapt the product to a new market; absence of restrictions on the sale of the offered product (provision of services) in the desired market; insignificant barriers to exit the market through the use of available infrastructure;

- PBU is the high return on investment.

The best performance of hybrid growth is traced to enterprises of the tourist industry, which is due to the ease of allocation in their composition of SBU, HBU and PBU. Our research on the activities of the Zakhar Berkoot ski resort confirms the efficiency of the allocation of business units at the expense of a synergistic effect. However, in the 


\section{Hybrid Development of Modern Enterprises}

event that the company does not have a sufficient amount of its own financial resources and strategic capabilities, it is difficult or impossible to achieve such a result. Necessary new approaches based on the above hybrid growth features. For example, you can consider the activities of the resort "Ski Center Polyana" (hereinafter "SCP"), which consists of a hotel and a ski lift.

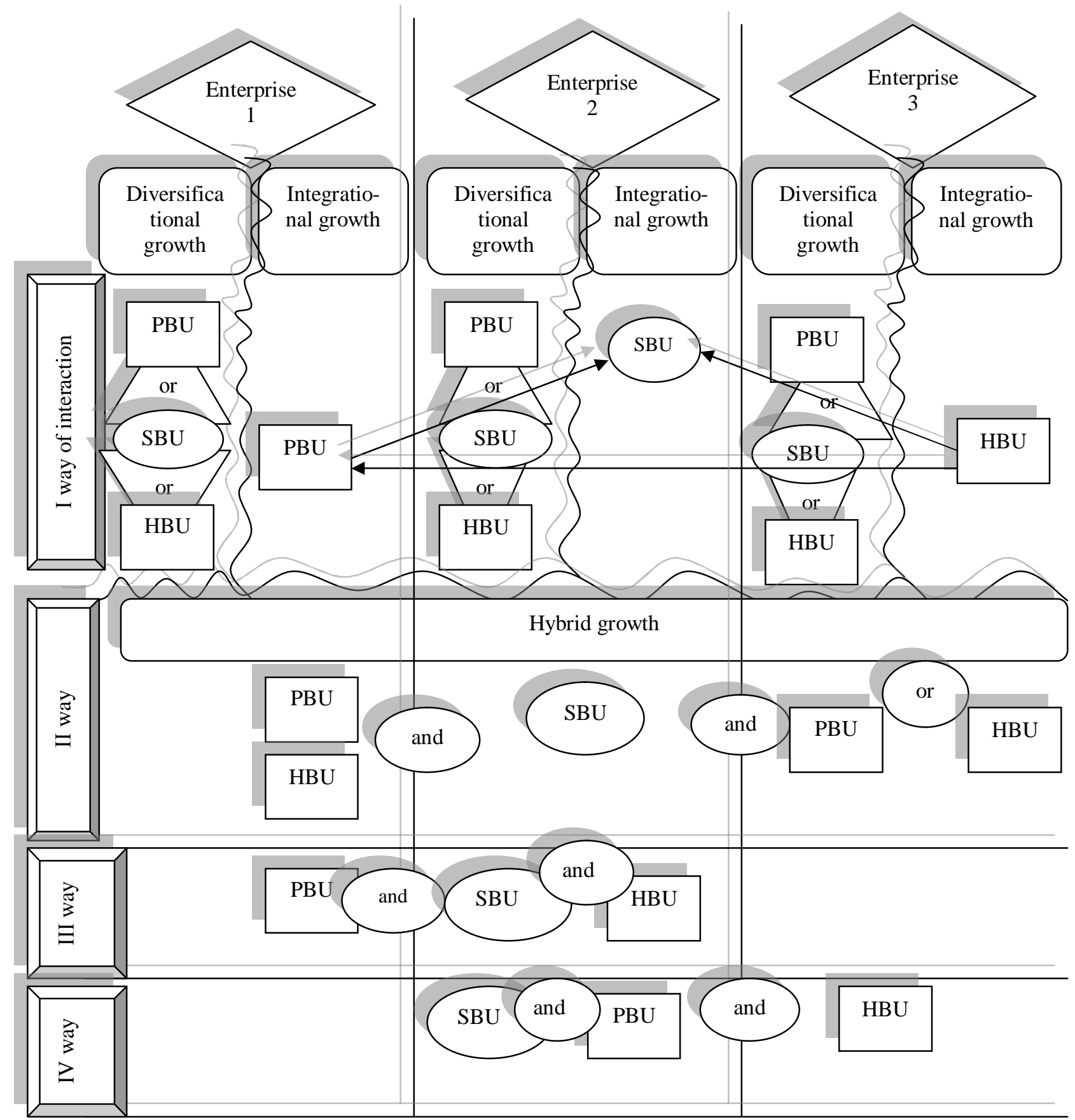

Fig. 1. Options for hybrid growth of enterprises [self-design project]

The division of the resort "Ski Center Polyana" on the SBU "hotel complex" and the "Ski Complex" PBU did not bring the desired results (encouraging a certain number of consumers), although the proposed division allowed outlines directions and variants of hybrid growth. That is, for the development of the existing resort, taking into account the variants of hybrid growth presented in Fig. 1, it is proposed to use concentric diversification by expanding the spectrum of existing services with new ones with corresponding directions of integration development of the interaction of the own business units of the resort with the structural units of other enterprises (Figure 2). 


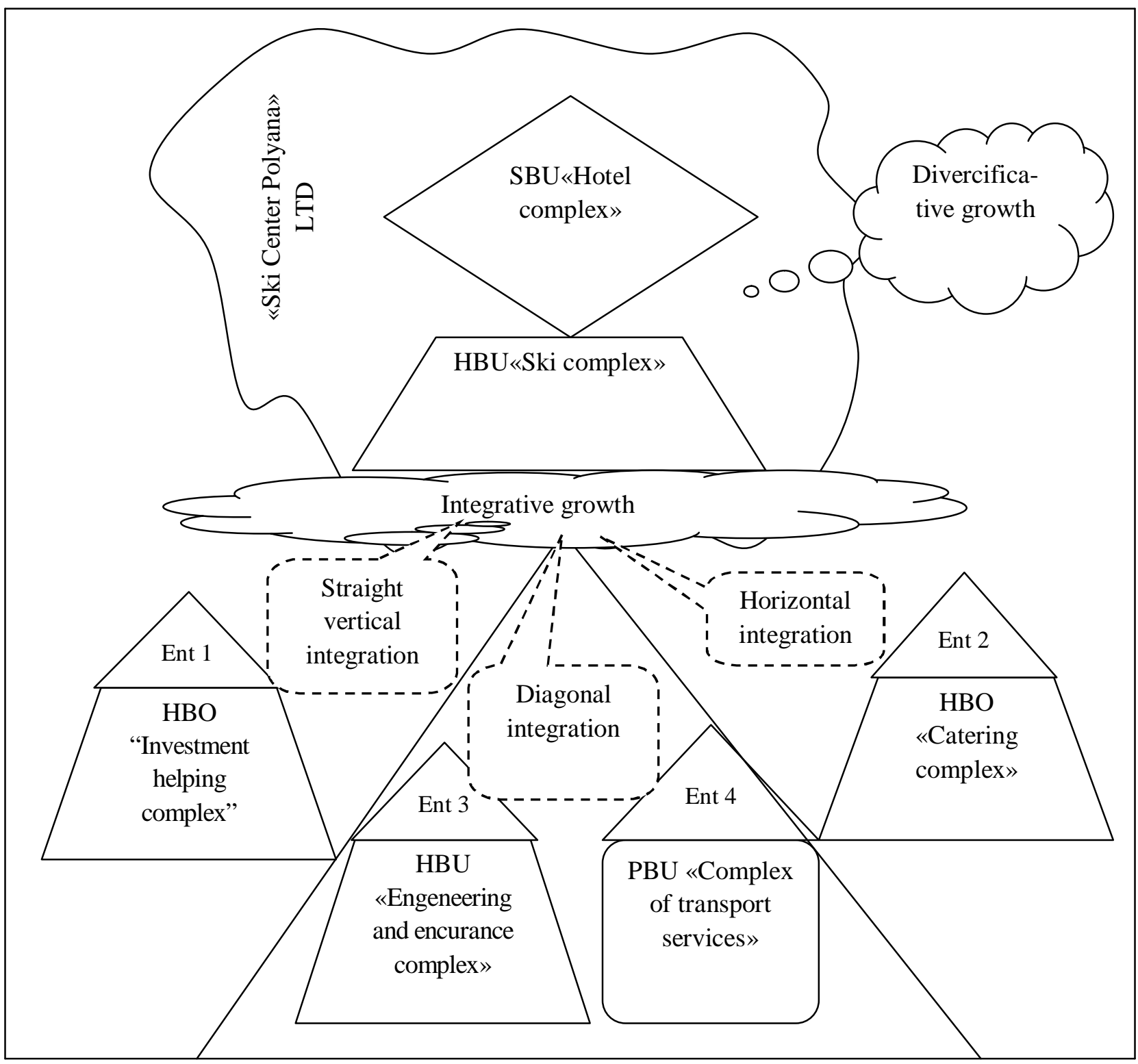

Fig. 2. Option of hybrid growth of "Ski Center Polyana" Ltd [self-design project]

Consequently, it is necessary to combine the researched resort with the following structures:

- Public catering complex (outbound services). This complex will be presented by small traders who will sell their products near the ski lifts and descents of the resort and only with the permission of the management. This facility will act as a supportive business unit, as it will not support the activities of the researched resort, will not promote the interest of customers, and will bring only certain cash;

- a complex of transport services (sphere of transport services). The complex will also be presented by a private owner, but it will support the resort's activities, as it will boost consumers and will work mainly to ensure the livelihood of the resort. Therefore, it will act as a unit providing business;
- investment and auxiliary complex. In our case, this will be a supporting business unit and will be a travel agency that will organize recreational and sports entertainment for both adults and children;

- the engineering and insurance complex is represented by a special company, which provides a set of services for the maintenance of engineering networks, transformer substation, life insurance, as well as rescue services. In our case, it will also be a supporting business unit.

Integration strategy is presented in three types: direct vertical integration with travel companies, horizontal integration with retailers and diagonal integration with transportation and rescue organizations. 
The effectiveness of selected strategic development directions of "SCP" Ltd. is confirmed by the results obtained from their implementation.
For weight and necessity of realization of the chosen directions in tab. 1 discussed several possible options for the development of the resort "SCP" Ltd. and calculated the possible results of each of them.

\section{Results of realization of selected directions of strategic development of the resortment of a larger amount of investment}

\begin{tabular}{|c|c|c|c|c|c|c|}
\hline \multirow[b]{2}{*}{ Indexes } & \multicolumn{6}{|c|}{ The results of "Ski Center Polyana" Ltd. activity } \\
\hline & $\begin{array}{c}\text { Without } \\
\text { using of } \\
\text { any } \\
\text { strategy } \\
\text { (2015) }\end{array}$ & $\begin{array}{l}\text { Using the } \\
\text { strategy of } \\
\text { concentric } \\
\text { growth } \\
(2016)\end{array}$ & $\begin{array}{l}\text { Using the } \\
\text { strategy of } \\
\text { concentric } \\
\text { diversifica-tion }\end{array}$ & \multicolumn{2}{|c|}{$\begin{array}{l}\text { With the } \\
\text { chosen } \\
\text { strategy of } \\
\text { hybrid } \\
\text { growth }\end{array}$} & $\begin{array}{l}\text { Using the } \\
\text { strategy of } \\
\text { conglomera } \\
\text { tivediversifi } \\
\text { ca-tion }\end{array}$ \\
\hline Investment costs, UAH ths. & - & 1200 & 2750,38 & \multicolumn{2}{|c|}{2750,38} & 5175,07 \\
\hline $\begin{array}{l}\text { Revenues from the sale of } \\
\text { tourist resort services, ths. } \\
\text { UAH, in particular: }\end{array}$ & 3456 & 6532 & 9144,8 & \multicolumn{2}{|c|}{13538,78} & 15167,82 \\
\hline $\begin{array}{l}\text { Revenue from } \\
\text { realization of services of the } \\
\text { ski complex, ths. UAH. }\end{array}$ & - & - & 5083 & \multicolumn{2}{|c|}{7014,54} & 7014,54 \\
\hline $\begin{array}{l}\text { Revenues from the sale of hotel } \\
\text { complex services, ths. UAH }\end{array}$ & - & - & 4061,8 & \multicolumn{2}{|c|}{6506,24} & 4879,68 \\
\hline $\begin{array}{l}\text { Revenues from the sale of } \\
\text { catering services, ths. UAH. }\end{array}$ & - & - & - & \multicolumn{2}{|c|}{18} & 2930,37 \\
\hline $\begin{array}{l}\text { Revenues from the sale of } \\
\text { services of the transport } \\
\text { complex, ths. UAH. }\end{array}$ & - & - & - & \multicolumn{2}{|c|}{$(292,27)$} & 145 \\
\hline $\begin{array}{l}\text { Revenue from the sale of } \\
\text { services of the investment and } \\
\text { auxiliary complex, ths. UAH }\end{array}$ & - & - & - & \multicolumn{2}{|c|}{$(227,96)$} & 198,23 \\
\hline $\begin{array}{l}\text { Revenue from the sale of } \\
\text { engineering and insurance } \\
\text { complex services, ths. UAH. }\end{array}$ & - & - & - & \multicolumn{2}{|c|}{$(234,5)$} & - \\
\hline $\begin{array}{l}\text { Costs of operating activities of } \\
\text { the resort, ths. UAH, in } \\
\text { particular: }\end{array}$ & 4033 & 5506,58 & 5612 & \multicolumn{2}{|c|}{6310,43} & 7380,26 \\
\hline $\begin{array}{l}\text { The costs of the ski resort, ths. } \\
\text { UAH. }\end{array}$ & \multirow{2}{*}{4033} & \multirow{2}{*}{5506,58} & 1683 & 2244 & \multirow{2}{*}{5612} & 2903,38 \\
\hline $\begin{array}{l}\text { Costs of the hotel complex, } \\
\text { ths. UAH }\end{array}$ & & & 3929 & 3368 & & 1907,58 \\
\hline $\begin{array}{l}\text { Expenses of the complex of } \\
\text { public catering, ths. UAH. }\end{array}$ & - & - & - & \multicolumn{2}{|c|}{-} & 2200 \\
\hline $\begin{array}{l}\text { Expenses of the transport } \\
\text { complex, thousand UAH }\end{array}$ & - & - & - & \multicolumn{2}{|c|}{265,7} & 206 \\
\hline $\begin{array}{l}\text { Expenses of the investment and } \\
\text { auxiliary complex, ths. UAH }\end{array}$ & - & - & - & \multicolumn{2}{|c|}{198,23} & 98,3 \\
\hline $\begin{array}{l}\text { Expenses of engineering and } \\
\text { insurance complex, ths. UAH }\end{array}$ & - & - & - & \multicolumn{2}{|c|}{234,5} & 65 \\
\hline Profit before taxes, ths. UAH & -577 & 1025,42 & 3532,8 & \multicolumn{2}{|c|}{7228,35} & 7787,56 \\
\hline Income tax, ths. UAH & - & 184,57 & 635,9 & \multicolumn{2}{|c|}{1301,103} & 1401,76 \\
\hline Profit after taxes, ths. UAH & 577 & 869 & 2896,9 & \multicolumn{2}{|c|}{5927,25} & 6385,79 \\
\hline
\end{tabular}




\section{Kozyk, Kh. Zalytska, V. Zalutsky}

The first option is the activity of the resort of "SCP" Ltd. without the use of any strategy. Just so, the resort functioned until 2016. During this period, his activities were loss-making due to low incomes and high costs, and the management did not invest any funds in the activities of the resort. The ineffective activity of the resort forced the management to review the company's policy, assess its own capabilities and market needs and, on the basis of this, form a new direction for further development.

This direction has been concentric growth, which envisaged improvement of the company by improving and expanding the list of certain types of services, reducing the cost of providing services, etc. It is clear that such measures required certain cash, which the enterprise practically did not have and the management turned to investors. Of course, the use of this strategic direction of development allowed the resort to increase the number of customers, and accordingly, and profits. However, for a long time to stay at this level, due to the diversification of the resort services prevented by competitors, who also actively began searching for ways to reduce the prices of services or to improve and diversify them.

The results of research on the activities of promising domestic and foreign enterprises have confirmed the effectiveness of diversified growth. However, the limited amount of money allowed using only concentric diversification, the essence of which was to focus on their own needs in order to improve the quality of existing services and develop new promising services to create the maximum possible synergy effect. Such synergistic specialization allowed increasing the company's income by $40 \%$, with an increase in costs by only $15 \%$. It is clear that the formation of additional services required the invest.

The application of the hybrid strategy required the same investment as for concentric diversification, since in two cases there were only two business units in the enterprise, and only the quality of services, their list and costs for their implementation changed accordingly. The merger of the resort "SCP" Ltd. with the enterprises and business units of other enterprises strengthened its attractiveness, increased the number of consumers, and, accordingly, the amount of income by $30 \%$ compared with concentric diversified growth. At the same time, the availability of transport services increased the income of the ski resort by $15 \%$, and the hotel - by $10 \%$, the complex of public catering increased incomes of the ski resort by 5\%; travel companies provided growth of both business units by $15 \%$, and the engineering and insurance complex by reducing the downtime of the equipment of the resort due to breakage and the availability of rescuers increased revenues and hotel and ski resort by $3 \%$. With a hybrid growth, the catering complex consisted of outlets at the ski lifts, which provided income in the form of a lease. The restaurant in this case belonged to the hotel complex. Identification of a business unit catering complex did not provide a large number of customers and did not bring significant profits, however, allowed to restrict and take control of the work of outlets.

With hybrid growth, the cost of the "SCP" Ltd. remained constant, and additional costs began to pay for services to outsized business units, whose incomes were corresponding to their payments to the resort "SCP" Ltd. But apart from the "SCP" Ltd., enterprises whose business units cooperated with this resort, served several other enterprises, not only the tourism industry. Thus, for example, travel companies that acted for the "SCP" Ltd. as a "investment and auxiliary complex" were receiving money from the resort, and for its part provided its activities to a certain number of clients. The very successful proposal was the formation of children's groups for sporting and recreational activities. Adoption of a group of children allowed the resort and available children's rooms and playgrounds, as well as attached multilifts and equipped with a walk-in closet. Of course, the inflow of customers increased the volume of services and hotel, and bugles, and transport. We did not include incomes of affiliated business units in the total income of the resort, since these are personal revenues of these structures, which consist of two parts - payments by the Ski Center Polyana Ltd. for services rendered plus $10 \%$ for the transport complex and $15 \%$ for travel companies that they earned an accompanying rendering of a resort service (the size of their profits for clarity is given in round brackets). 


\section{Hybrid Development of Modern Enterprises}

The cost of applying this strategy and the amount of profit may vary, respectively, in the direction of reduction and increase by establishing the most effective options for enhancing some business units at the expense of others. Such profitability requires for a longer period of research.

In addition to the hybrid growth strategy as an option for effective long-term development of the resort (which was used by the Zakhar Berkoot spa resort), Table 1 shows the indicators of conglomerate diversification, which involves replenishing the company's range of products that are not related to either the technology used or the the markets in which the firm operates, or with the existing needs of consumers. The strategy of conglomerate diversification is considered for comparison, if all integration business units were present at the studied resort.

However, at the moment, the practical use of this strategic alternative is not feasible due to lack of funds. It is clear that conglomerate diversification requires a much larger amount of investment, due to the creation of infrastructure and the purchase or construction of objects of the proposed business units (purchase of transport, opening an office for a tour of the company, etc.). With conglomerate diversification, hotel revenues would fall by $25 \%$ because restaurant services with self-generated outbound points of sale would be part of a catering complex. In this case, the revenues of the transport complex would be $10 \%$ higher due to the fact that we would independently provide these services and, accordingly, would more clearly indicate the number of all passengers transported. In the minus left only the engineering and insurance complex, which is connected with the use of services of specialized rescue and security companies. It is clear that the effectiveness of the conglomerate development option can be much higher than the hybrid variant if it is true to form and realize a synergistic effect. However, with a low financial position and an overly threatening external environment, the implementation of the conglomerate diversification option is too risky and usually costly due to the need to attract a large amount of investment.

Consequently, a hybrid strategy is effective in an unattractive or critical financial condition, but the available opportunities (marketing, innovation, personnel, etc.) continue to grow. In addition, as can be seen from Table. the obtained results of the implementation of the hybrid variant of development at the enterprise are not very different from the results of conglomerate diversification. Of course, by improving its activity due to hybrid growth, the resort may gradually create some business units on its own, but it is expedient to attract from the side specialized services on certain services with high quality, low cost, variety of assortment, etc. business unit for effective longterm growth.

It will be more complicated to use hybrid growth options for enterprises that are difficult to clearly distinguish between SBUs, HBUs and PBUs. In this case, a closer examination of the need for a clearer definition of the critical points of contact between business units of different enterprises, determination of the time of termination of own production and association with specialized enterprises or their business units, etc., are needed. The best way to establish links between the allocated SBU, HBU and PBU of different enterprises will be through the relationship between universally allocated for all businesses business processes of specific business units and their respective components.

\section{Conclusions and perspectives of further research}

The conducted studies allowed us to conclude that:

- From the theoretical point of view, the hybrid growth strategy can be used by all enterprises, regardless of their strategic capabilities and development stages, without contradictions and dependencies from other enterprises by establishing a rational balance between competition and cooperation. This variant of development is based on the peculiarities of diversification and integration growth with the formation of the appropriate variants of interaction of specific business units of different enterprises;

- From a practical point of view, the hybrid growth option is effective because of the possibility of its use for enterprises without significant financial resources in order to: rapidly and stably increase the corresponding strategic capabilities by specializing in certain business units; rapid balance 


\section{Kozyk, Kh. Zalytska, V. Zalutsky}

of the enterprise portfolio, which involves the involvement of business units at the appropriate stage of the life cycle; effective entry into international markets, where products will be treated as national ones, etc.

Consideration of the possibilities and difficulties of using hybrid growth options for enterprises of different ownership forms of all industries has allowed to outline the prospects for further research in the direction of the formation of methodological provisions for the allocation of critical points of contact between business units of different enterprises, by their division into universal constituent elements (business processes).

\section{References}

1. Butenko, NV (2003). Diversification of production: goals and strategies for implementation. Economy of agroindustrial complex, 7, 109-114 [in Ukrainian].

2. Semenov, G.A, \& Kremenchutska, Yu.R. (2012). Diversification as a factor in stabilizing the sustainable development of the enterprise. State and regions. Series: Economics and Business, 3, 215-220 [in Ukrainian].

3. Rudyk, N. B. (2005). Conglomerate mergers and acquisitions. A book about the benefits and harms of non-core assets. Moscow: Delo [in Russian].

4. Petrov, V.M. (2010). Typology of production diversification in planning the strategic development of an industrial company. Journal of Economic Sciences. Questions of theory and practice, 5(66), 88-91 [in Russian].

5. Shevchuk, I. (2007). Strategies for diversifying the activities of a transnational company in terms of its target function. Bulletin of the Kiev National University named after. T. Shevchenko: Economics, 98, 53-56 [in Ukrainian].

6. Gosteva, I.S. (n.d.) Concepts and types of integrated enterprises. Retrieved from http:// www. dspace.snu.edu.ua:8080/jspui/bitstream/ 123456789/601/1/gosteva.pdf 90 [in Ukrainian].
7. Salimova, L.R. (2011). Factors of formation of corporate associations of conglomerate type. Bulletin of SamGu, 9(90), 97-100 [in Russian].

8. Alekseev, I.V., \& Bondarenko, L.P. (2010). Formation of integration unions on the basis of industrial and financial groups as a factor in the development of innovation activities in Ukraine. BusinessInform, 11, 108-111 [in Ukrainian].

9. Kovalevskaya, K.A. (2009). Modern forms of integrated enterprises in the conditions of globalization. Actual problems of the economy, 5(95), 145-148 [in Ukrainian].

10. Zverbny, A.S., \& Drimalovskaya, Kh. V. (2013). Diversification in integrated structures in a globalizing environment. Scientific and Theoretical Journal of Khmelnytskyi Economic University "Science and Economics", 4(32), 118123 [in Ukrainian].

11. Kuzmin, O.E., Feshchur, R.V., \& Drimalovskaya, Kh.V. (2015). Concept and tools of the project's departure to diversify the activities of the enterprise. Actual problems of the economy, 12(174), 415-422 [in Ukrainian].

12. Skybinskyy, O.S., \& Drymalovska, Ch. V. (2014). Analisys of diversification on machine-building enterprises: innovative approach. Economics, Entrepreneursip, Management, 2, 55-59 [in English].

13. Kozyk, V.V., \& Zalutska, Kh .Ya. (2017). Formation of interaction of participants of diversified companies through the strategy of behavior of their business units. Formation and development of interaction of participants of innovation infrastructure: theoretical and applied aspects, (pp. 98-111). Lviv: Rastr-7 [in Ukrainian].

14. Kozyk, V.V., \& Zalutska, Kh .Ya. (2016). Features of the functioning of diversified companie. Journal «The scientific heritage», Vol. 1, 3 (3), 4-6 [in Ukrainian].

15. Kozyk, V.V., \& Zalutska, Kh .Ya. (2017). Formation of business units of diversified enterprises. Actual problems of the economy, №3 (189), 116-123 [in Ukrainian]. 